\title{
Short, Enantioselective Total Synthesis of Aflatoxin $B_{2}$ Using a New Asymmetric [3+2]-Cycloaddition Step
}

\author{
Gang Zhou and E. J. Corey* \\ Department of Chemistry and Chemical Biology \\ Harvard University, Cambridge, Massachusetts, 02138, USA
}

\section{Index}

Part I. Synthesis of (-)-Aflatoxin $B_{2}$. S-3

Part II. Enantioselective [3+2] Reaction. S-10

$\begin{array}{lr}\text { Part III. Mechanism Study. } & \text { S-17 }\end{array}$

$\begin{array}{ll}\text { Part IV. X-ray Structures. } & \text { S-19 }\end{array}$ 


\section{Supplementary Materials}

Materials and Methods. Unless stated otherwise, reactions were performed in flame-dried glassware under a positive pressure of nitrogen using freshly distilled solvents. Thin-layer chromatography (TLC) was performed using E. Merck silica gel $60 \mathrm{~F}_{254}$ precoated plates $(0.25$ $\mathrm{mm})$. Flash chromatography was performed using Baker silica gel (40 $\mu \mathrm{m}$ particle size). NMR spectra were recorded on Varian Innova-400, or Mercury-400 instruments and calibrated using residual undeuterated solvent as an internal reference. IR spectra were recorded on Avatar 360 FT-IR spectrometer. Low-resolution mass (CI) spectra were obtained by using a Platform II mass spectrometer. High-resolution mass spectral analyses were performed at the Harvard University Mass Spectrometry Center. Analytical high performance liquid chromatography (HPLC) was performed on Isco 2350 Series or Waters 626 HPLC using the indicated chiral column. Gas chromatography (GC) analyses were performed on Hewlett-Packard 6850 Series GC System equipped with flame ionization detector using a J \& W Scientific Cyclosil-B column (30 $\mathrm{m} \times$ $0.25 \mathrm{~mm})$ or Chiraldex gamma-TA column $(30 \mathrm{~m} \times 0.25 \mathrm{~mm})$. Commercial grade reagents and solvents were used without further purification except as indicated below. Dichloromethane and acetonitrile were distilled from calcium hydride. Toluene was distilled from sodium. 2,3Dihydrofuran (Aldrich) was used after distillation. 2-Methoxy-1,4-benzoquinone (TCI) was used after recrystallization with benzene. 2,3-dimethylquinone (Aldrich), naphthalene-1,4-dione (Aldrich), and 1,4-benzoquinone (Aldrich) were used after recrystallization in a mixture of ether and hexanes. 2-methoxy-3-methyl-1,4-benzoquinon, 1 2-methoxy-3-isopropyl-1,4benzoquinone, $\quad 2$ 2-isopropyl-3-methoxy-5-methyl-1,4-benzoquinone $\quad 3$ and 2(dimethylphenylsilyl)-3,4-dihydrofuran ${ }^{4}$ were prepared according to literature procedures.

\footnotetext{
${ }^{1}$ Knolker, H.-J.; Frohner, W.; Reddy, K. R. Synthesis 2002, 4, 557-565.

2 (a) Erdtman, H. Proc. Roy. Soc. Ser. A. 1934, 143, 177-191. (b) Bargellim, G. Gazz. Chim. Ital. 1923, 53, 235245.

${ }^{3}$ Kende, A. S.; Bentley, T. J. J. Am. Chem. Soc. 1974, 96, 4333-4334.

${ }^{4}$ Yoshida, J.-i.; Maekawa, T.; Murata, T.; Matsunaga, S-i.; Isoe, S. J. Am. Chem. Soc. 1990, 112, 1962-1970.
} 


\section{Part I. Synthesis of (-)-Aflatoxin $\mathbf{B}_{2}$.}

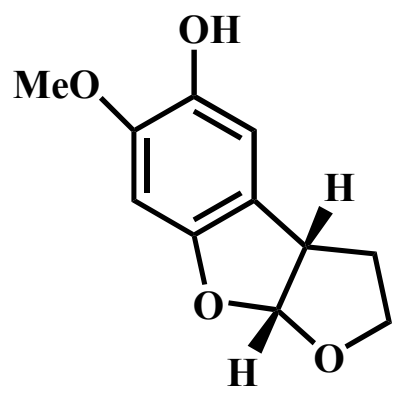

(-)-2,3,3aS,8aR-Tetrahydro-5-hydroxy-6-methoxy[2,3-d]-benzo[b]furan (2). A $100 \mathrm{~mL}$ round-bottomed flask was fitted with a Dean-Stark apparatus that was charged with $\mathrm{ca} .20 \mathrm{~g}$ of $4 \AA$ molecular sieves. Tri-o-tolylboroxine (140 mg, $0.4 \mathrm{mmol}),(R)-(-)$ - $\alpha, \alpha$-diphenyl-2pyrrolidinemethanol $^{5}(302 \mathrm{mg}, 1.2 \mathrm{mmol})$ and toluene $(30 \mathrm{~mL})$ were added into the above flask. The resulting solution was stirred at room temperature for $30 \mathrm{~min}$, and then heated at reflux (bath temperature $\sim 140{ }^{\circ} \mathrm{C}$ ). After $16 \mathrm{~h}$, the mixture was concentrated by removing solvent from the Dean-Stark apparatus, to a volume of $c a .3 \mathrm{~mL}$. The reaction mixture was cooled to room temperature, and the Dean-Stark apparatus was quickly replaced with a nitrogen inlet adaptor. Concentration in vacuo (ca. $0.1 \mathrm{mmHg}, 1 \mathrm{~h}$ ) afforded the corresponding oxazaborolidine as clear oil, which was then dissolved in $\mathrm{CH}_{2} \mathrm{Cl}_{2}$. To a solution of the oxazaborolidine $(1.2 \mathrm{mmol}$, theoretical) in $4 \mathrm{~mL}$ of $\mathrm{CH}_{2} \mathrm{Cl}_{2}$ at $-20{ }^{\circ} \mathrm{C}$ was added dropwise trifluoromethanesulfonimide $(0.50$ $\mathrm{M}$ solution in $\mathrm{CH}_{2} \mathrm{Cl}_{2}$, freshly prepared, $2 \mathrm{~mL}, 1.0 \mathrm{mmol}$ ). After $15 \mathrm{~min}$ at $-20{ }^{\circ} \mathrm{C}$, a colorless homogeneous catalyst $\mathbf{A}$ solution was ready for further reaction use.

The pre-mixed solution of 2-methoxy-1,4- benzoquinone $(690 \mathrm{mg}, 5 \mathrm{mmol})$ and dihydrofuran $\left(525 \mathrm{mg}, 7.5 \mathrm{mmol}\right.$ ) in $5 \mathrm{ml}$ of anhydrous $\mathrm{CH}_{3} \mathrm{CN}$ was added to the catalyst $\mathbf{A}$ solution dropwise during $3 \mathrm{~h}$ by syringe pump. Then the reaction mixture was allowed to warm to room temperature slowly for $5 \mathrm{~h}$. After the reaction was complete, $\mathrm{MeOH}(2 \mathrm{~mL})$ and $\mathrm{H}_{2} \mathrm{O}$

\footnotetext{
${ }^{5}$ Purchased from Sigma-Aldrich Co. and used without further purification.
} 
$(10 \mathrm{~mL})$ were added to the reaction mixture. The aqueous layer was extracted with $\mathrm{CH}_{2} \mathrm{Cl}_{2}(4 \times$ $50 \mathrm{~mL}$ ). The combined organic layers were washed with water, brine and dried over $\mathrm{Na}_{2} \mathrm{SO}_{4}$. After concentration in vacuo, the residue was purified by flash chromatography on silica gel (elution with $1: 1$ to $2: 1$ ether/hexanes) to give the (-)-2,3,3aS,8aR-tetrahydro-5-hydroxy-6methoxy[2,3-d]-benzo[b]furan (2) (676mg, 65\%) and (-)-2,3,3aS,8aR-tetrahydro-5-hydroxy-7methoxy[2,3-d]-benzo[b]furan (333 mg, 32\%) compound as white solid.

(-)-2: $\operatorname{mp~151-152~}{ }^{\circ} \mathrm{C} ;{ }^{1} \mathrm{H}$ NMR $\left(400 \mathrm{MHz}, \mathrm{CDCl}_{3}\right) \delta 6.74(\mathrm{~d}, 1 \mathrm{H}, J=0.8 \mathrm{~Hz}), 6.41(\mathrm{~s}, 1 \mathrm{H})$, $6.25(\mathrm{~d}, 1 \mathrm{H}, J=6.4 \mathrm{~Hz}), 5.26(\mathrm{~s}, 1 \mathrm{H}, \mathrm{OH}), 4.04(\mathrm{t}, 1 \mathrm{H}, J=8.0 \mathrm{~Hz}), 3.94(\mathrm{dd}, 1 \mathrm{H}, J=7.8,6.0$ $\mathrm{Hz}), 3.84(\mathrm{~s}, 3 \mathrm{H}), 3.57-3.63(\mathrm{~m}, 1 \mathrm{H}), 2.18-2.28(\mathrm{~m}, 1 \mathrm{H}), 2.01(\mathrm{dd}, 1 \mathrm{H}, J=12.0,4.8 \mathrm{~Hz}) ;{ }^{13} \mathrm{C}$ NMR $\left(100 \mathrm{MHz}, \mathrm{CDCl}_{3}\right) \delta 153.0,146.9,140.4,118.5,111.5,110.3,93.9,67.5,56.4,47.1,33.7$; FTIR (neat) 3049, 2925, 2854, 1497, 1158, 957; LRMS (CI) calcd for $\left[\mathrm{C}_{11} \mathrm{H}_{13} \mathrm{O}_{4}\right]\left([\mathrm{MH}]^{+}\right) 209$; found $209 ;[\alpha]_{\mathrm{D}}^{23}-88\left(c 1.0, \mathrm{CHCl}_{3}, 92 \% e e\right)$. After recrystallized from ether, optical pure (-)2,3,3aS,8aR-tetrahydro-5-hydroxy-6-methoxy[2,3- $d]$-benzo[b]furan (-)-2 was obtained: $[\alpha]_{\mathrm{D}}^{23}$ 96 (c 1.0, $\mathrm{CHCl}_{3},>99 \%$ ee). Enantioselectivity was determined by $\mathrm{GC}$ analysis using a $\mathrm{J} \& \mathrm{~W}$ Scientific Cyclosil-B column $\left(30 \mathrm{~m} \times 0.25 \mathrm{~mm}, 170{ }^{\circ} \mathrm{C}, 25 \mathrm{psi}\right)$; retention times: $31.9 \mathrm{~min}$ (major), $33.1 \mathrm{~min}$ (minor). The absolute configuration was assigned by X-ray crystallographic analysis of 2,3,3aS,8aR-tetrahydro-5-(4-bromobenzyl)-6-methoxy-[2,3-d]-benzo[b]furan.

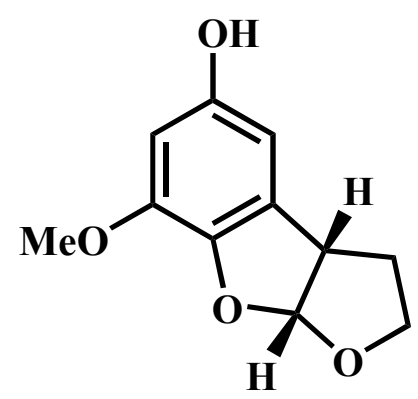

Regioisomer-(2): Enantioselectivity was determined by GC analysis using a J \& W Scientific Cyclosil-B column $\left(30 \mathrm{~m} \times 0.25 \mathrm{~mm}, 170{ }^{\circ} \mathrm{C}, 25 \mathrm{psi}\right)$; retention times: $51.8 \mathrm{~min}$ (major), 54.9 min (minor). The absolute configuration was assigned by X-ray crystallographic analysis and analogy with (-)-2,3,3aS,8aR-tetrahydro-5-hydroxy-6-methoxy[2,3-d]-benzo[b]furan: mp 154- 
$155{ }^{\circ} \mathrm{C} ;{ }^{1} \mathrm{H}$ NMR $\left(400 \mathrm{MHz}, \mathrm{CDCl}_{3}\right) \delta 6.30(\mathrm{~m}, 2 \mathrm{H}), 6.28(\mathrm{~d}, 1 \mathrm{H}, J=1.2 \mathrm{~Hz}), 4.69(\mathrm{~s}, 1 \mathrm{H})$, $4.06(\mathrm{t}, 1 \mathrm{H}, J=8.4 \mathrm{~Hz}), 3.93(\mathrm{dd}, 1 \mathrm{H}, J=12.0,8.4 \mathrm{~Hz}), 3.80$ (s, $3 \mathrm{H}), 3.59-3.65$ (m, $1 \mathrm{H}), 2.18$ 2.28 (m, $1 \mathrm{H}), 2.02$ (dd, $1 \mathrm{H}, J=16.4,6.8 \mathrm{~Hz}$ ); FTIR (neat) 3357, 2975, 2846, 1629, 1495, 1345, 1065, 943; LRMS (CI) calcd for $\left[\mathrm{C}_{11} \mathrm{H}_{13} \mathrm{O}_{4}\right]\left([\mathrm{MH}]^{+}\right)$209; found 209; $[\alpha]_{\mathrm{D}}^{23}+93$ (c 2.0, $\mathrm{CHCl}_{3}$, $90 \% e e)$.

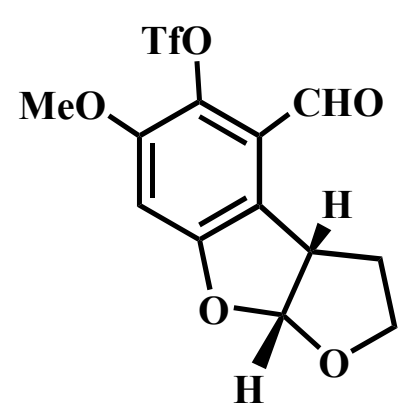

(-)- cis - 5 - Trifluoromethanesulfonyloxy - 2, 3, 3aS, 8aR-tetrahydro - 6 - methoxy [2, 3$\boldsymbol{d}$ ]-benzo[b]furan-4-carboxaldehyde (3). To a solution of phenol 2 (0.54 g, $2.5 \mathrm{mmol})$ in glacial $\mathrm{AcOH}(10 \mathrm{ml})$ in a screw-top sealed tube, hexamethylenetetramine $(0.70 \mathrm{~g}, 5 \mathrm{mmol})$ was added. The resulting mixture was heated with stirring at $110{ }^{\circ} \mathrm{C}$ for $48 \mathrm{~h}$. A $33 \%$ aqueous $\mathrm{H}_{2} \mathrm{SO}_{4}$ solution $(7 \mathrm{~mL})$ was added and the resulted solution was heated at $75^{\circ} \mathrm{C}$ for $1 \mathrm{~h}$ and then cooled to room temperature before diluted with water $(20 \mathrm{ml})$. The mixture was extracted with $\mathrm{CH}_{2} \mathrm{Cl}_{2}$ $(6 \times 100 \mathrm{~mL})$ and the combined organic phase was washed with brine $(3 \times 10 \mathrm{~mL})$, dried over $\mathrm{Na}_{2} \mathrm{SO}_{4}$. After concentrated in vacuo, the pale yellow oily residue was purified by chromatography on silica gel (elution with 1:1:0.02 EtOAc/hexanes/AcOH) to afford $236 \mathrm{mg}$ $(40 \%)$ of (-) - 2, 3, 3aS, $8 a R$ - tetrahydro- 5 - hydroxy - 6 -methoxy[2, 3 - d]-benzo[b]furan - 4 carboxaldehyde as a yellow oil, which crystallized upon standing: mp 151.0-152.0 ${ }^{\circ} \mathrm{C} ;{ }^{1} \mathrm{H}$ NMR $\left(400 \mathrm{MHz}, \mathrm{CDCl}_{3}\right) \delta 10.17(\mathrm{~s}, 1 \mathrm{H}), 6.64(\mathrm{~s}, 1 \mathrm{H}), 6.37$ (d, $\left.1 \mathrm{H}, J=5.7 \mathrm{~Hz}\right), 4.27(\mathrm{dd}, 1 \mathrm{H}, J=8.7$, $6.6 \mathrm{~Hz}), 4.09$ (t, $1 \mathrm{H}, J=6.0 \mathrm{~Hz}), 3.85(\mathrm{~s}, 3 \mathrm{H}), 3.61-3.69(\mathrm{~m}, 1 \mathrm{H}), 2.33-2.42(\mathrm{~m}, 1 \mathrm{H}), 2.00$ (dd, $1 \mathrm{H}, J=12.3,5.1 \mathrm{~Hz}) ;{ }^{13} \mathrm{C} \mathrm{NMR}\left(100 \mathrm{MHz}, \mathrm{CDCl}_{3}\right) \delta 193.2,152.3,149.0,146.9,117.8,116.1$, 112.2, 101.6, 67.3, 56.7, 45.8, 34.4; FTIR (neat) 3010, 2965, 2940, 1675, 1445, 939; LRMS (CI) calcd for $\left[\mathrm{C}_{12} \mathrm{H}_{13} \mathrm{O}_{5}\right]\left([\mathrm{MH}]^{+}\right) 237$; found $237 ;[\alpha]_{\mathrm{D}}^{23}-104\left(c 1.3, \mathrm{CHCl}_{3}\right)$. 
To a stirred solution of DMAP (7.4 mg, $0.06 \mathrm{mmol})$, aldehyde described above (177 mg, $0.75 \mathrm{~mol})$ in pyridine $(7 \mathrm{~mL})$ and $\mathrm{CH}_{2} \mathrm{Cl}_{2}(7 \mathrm{~mL})$ was added triflic anhydride $(0.25 \mathrm{ml}, 1.5 \mathrm{mmol})$ dropwise at $-20{ }^{\circ} \mathrm{C}$, and the reaction mixture was stirred for $2 \mathrm{~h}$ at $0^{\circ} \mathrm{C}$. Water $(30 \mathrm{~mL})$ and ether $(30 \mathrm{~mL})$ were added. The aqueous layer was extracted with ether $(3 \times 30 \mathrm{~mL})$. The combined ether layers were washed successively with $1 \mathrm{~N} \mathrm{HCl}(3 \times 10 \mathrm{~mL})$, brine $(2 \times 10 \mathrm{~mL})$, and dried over $\mathrm{Na}_{2} \mathrm{SO}_{4}$ and concentrated in vacuo to give pale yellow oily residue. The residue was purified by chromatography on silica gel (gradient elution with 10-20\% EtOAc in hexanes) to afford $220 \mathrm{mg}(80 \%)$ of product 3 as a white solid: $\mathrm{mp}$ 103.0-104.0 ${ }^{\circ} \mathrm{C} ;{ }^{1} \mathrm{H}$ NMR (400 MHz, $\left.\mathrm{CDCl}_{3}\right) \delta 10.33(\mathrm{~s}, 1 \mathrm{H}), 6.74(\mathrm{~s}, 1 \mathrm{H}), 6.42(\mathrm{~d}, 1 \mathrm{H}, J=5.6 \mathrm{~Hz}), 4.33(\mathrm{dd}, 1 \mathrm{H}, J=9.6,6.8 \mathrm{~Hz})$, 4.09 (t, $1 \mathrm{H}, J=8.0 \mathrm{~Hz}), 3.91(\mathrm{~s}, 3 \mathrm{H}), 3.58-3.64(\mathrm{~m}, 1 \mathrm{H}), 2.40-2.45(\mathrm{~m}, 1 \mathrm{H}), 2.01$ (dd, $1 \mathrm{H}, J=$ 13.2, $4.8 \mathrm{~Hz}){ }^{13} \mathrm{C} \mathrm{NMR}\left(100 \mathrm{MHz}, \mathrm{CDCl}_{3}\right) \delta 187.3,159.9,152.7,134.6,125.3,120.8,119.0$ (q, $J_{\mathrm{C}-\mathrm{F}}=320 \mathrm{~Hz}$ ), 113.4, 100.1, 67.5, 56.9, 47.0, 33.5; FTIR (neat) 3010, 2958, 2925, 1695, 1450, 920; LRMS (CI) calcd for $\left[\mathrm{C}_{13} \mathrm{H}_{12} \mathrm{~F}_{3} \mathrm{O}_{7} \mathrm{~S}\right]\left([\mathrm{MH}]^{+}\right) 369$; found 369; $[\alpha]_{\mathrm{D}}^{23}-159\left(\right.$ c 2.3, $\left.\mathrm{CHCl}_{3}\right)$.

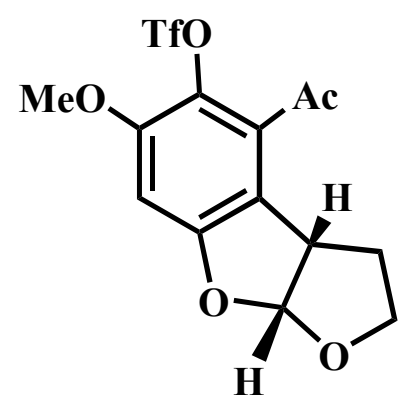

\section{(-)-cis-5-Trifluoromethanesulfonyloxy-2,3,3aS,8aR-tetrahydro-4-acetyl-6-methoxy-[2,3-d]-}

benzo[b]furan (4). A solution of $\mathrm{MeMgBr}\left(3.0 \mathrm{M}\right.$ in $\left.\mathrm{Et}_{2} \mathrm{O}, 0.33 \mathrm{~mL}, 1.0 \mathrm{mmol}\right)$ was added dropwise to a solution of $3(184 \mathrm{mg}, 0.5 \mathrm{mmol})$ in dry THF $(20 \mathrm{~mL})$ at $-20{ }^{\circ} \mathrm{C}$. After $2 \mathrm{~h}$, the reaction mixture was treated with saturated aqueous $\mathrm{NH}_{4} \mathrm{Cl}$ solution $(5.0 \mathrm{~mL})$. The mixture was extracted with ether $(3 \times 30 \mathrm{~mL})$. The combined ether layers were dried over $\mathrm{Na}_{2} \mathrm{SO}_{4}$, filtered through a pad of Celite ${ }^{\circledR}$, and concentrated in vacuo. The residue obtained (182 $\left.\mathrm{mg}, 0.48 \mathrm{mmol}\right)$ was then dissolved in in $30 \mathrm{~mL}$ of $\mathrm{CH}_{2} \mathrm{Cl}_{2}$, Dess-Martin periodinane $(0.43 \mathrm{~g}, 1 \mathrm{mmol})$ was added at $0{ }^{\circ} \mathrm{C}$. After stirring for $3 \mathrm{~h}$ at room temperature, the reaction mixture was diluted with ether 
$(30 \mathrm{~mL})$ and poured into $10 \mathrm{~mL}$ of saturated aqueous $\mathrm{NaHCO}_{3}$ solution and $10 \mathrm{~mL}$ of saturated aqueous $\mathrm{Na}_{2} \mathrm{~S}_{2} \mathrm{O}_{3}$ solution. The resulting mixture was stirred for $30 \mathrm{~min}$, extracted with ether (3 $\times 50 \mathrm{~mL}$ ) and the combined ether layers were washed with saturated aqueous $\mathrm{NaHCO}_{3}$ solution $(2 \times 10 \mathrm{~mL})$, brine and dried over $\mathrm{MgSO}_{4}$. The solvent was removed in vacuo and the residue was purified by chromatography on silica gel (elution with 10:1 hexanes/ether) to give the ketone 4 as a colorless oil (162 mg, 85\%): ${ }^{1} \mathrm{H}$ NMR (400 MHz, $\left.\mathrm{CDCl}_{3}\right) \delta 6.58(\mathrm{~s}, 1 \mathrm{H}), 6.37$ (d, $1 \mathrm{H}, J=6.0 \mathrm{~Hz}), 4.15(\mathrm{dd}, 1 \mathrm{H}, J=8.8,6.4 \mathrm{~Hz}), 4.09(\mathrm{t}, 1 \mathrm{H}, J=8.0 \mathrm{~Hz}), 3.88(\mathrm{~s}, 3 \mathrm{H}), 3.62-3.68$ (m, $1 \mathrm{H}), 2.59$ (s, $3 \mathrm{H}), 2.20-2.33(\mathrm{~m}, 1 \mathrm{H}), 1.87$ (dd, $1 \mathrm{H}, J=12.4,5.2 \mathrm{~Hz}) ;{ }^{13} \mathrm{C}$ NMR $(100 \mathrm{MHz}$, $\left.\mathrm{CDCl}_{3}\right) \delta 198.4,159.7,152.7,131.6,129.8,119.8\left(\mathrm{q}, J_{\mathrm{C}-\mathrm{F}}=315 \mathrm{~Hz}\right), 118.8,112.9,97.1,67.4$, 56.8, 46.2, 33.8, 31.7; FTIR (neat) 2980, 2955, 1700, 1418, 1199, 1136, 955; LRMS (CI) calcd for $\left[\mathrm{C}_{14} \mathrm{H}_{14} \mathrm{~F}_{3} \mathrm{O}_{7} \mathrm{~S}\right]\left([\mathrm{MH}]^{+}\right) 383$; found 383; $[\alpha]_{\mathrm{D}}^{23}-109\left(\right.$ c 2.8, $\left.\mathrm{CHCl}_{3}\right)$.

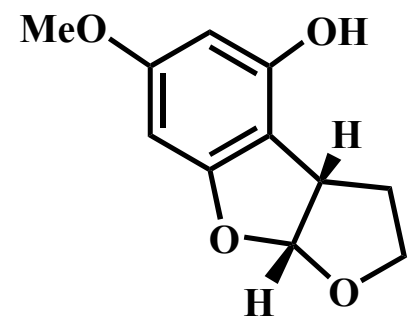

(-)-2,3,3aS,8aR-Tetrahydro-4-hydroxy-6-methoxy[2,3-d]-benzo[b]furan (5). TFAA (0.17 $\mathrm{mL}, 1.2 \mathrm{mmol})$ was added to a solution of urea- $\mathrm{H}_{2} \mathrm{O}_{2}$ complex $(376 \mathrm{mg}, 4 \mathrm{mmol})$ in $30 \mathrm{~mL}$ of $\mathrm{CH}_{2} \mathrm{Cl}_{2}$ dropwise with vigorous stirring. The reaction mixture was stirred for $1 \mathrm{~h}$ at room temperature and ketone 4 (150 mg, $0.40 \mathrm{mmol})$ was added in one portion. Another four portions of TFAA $(0.17 \mathrm{~mL}, 1.2 \mathrm{mmol})$ was added dropwise in every $10 \mathrm{~h}$. After the reaction was complete, the reaction mixture was extracted with $\mathrm{CH}_{2} \mathrm{Cl}_{2}(3 \times 30 \mathrm{~mL})$. The combined $\mathrm{CH}_{2} \mathrm{Cl}_{2}$ layers were washed with aq. $5 \% \mathrm{Na}_{2} \mathrm{SO}_{3} / 5 \% \mathrm{Na}_{2} \mathrm{HPO}_{4}(3 \times 10 \mathrm{~mL})$, brine, and dried over $\mathrm{Na}_{2} \mathrm{SO}_{4}$. The solvent was removed in vacuo and the residue was purified by chromatography on silica gel (elution with 10:1 hexanes/ether) to give the ester as a yellow oil $(99.5 \mathrm{mg}, 62.5 \%):{ }^{1} \mathrm{H}$ NMR (400 MHz, $\left.\mathrm{CDCl}_{3}\right) \delta 6.40(\mathrm{~s}, 1 \mathrm{H}), 6.36(\mathrm{~d}, 1 \mathrm{H}, J=6.4 \mathrm{~Hz}), 4.11(\mathrm{t}, 1 \mathrm{H}, J=8.8 \mathrm{~Hz}), 3.95$ (dd, $1 \mathrm{H}, J=8.4,6.0 \mathrm{~Hz}), 3.85(\mathrm{~s}, 3 \mathrm{H}), 3.64-3.70(\mathrm{~m}, 1 \mathrm{H}), 2.36(\mathrm{~s}, 3 \mathrm{H}), 2.10-2.18(\mathrm{~m}, 1 \mathrm{H})$, 
$1.99(\mathrm{dd}, 1 \mathrm{H}, J=12.4,5.2 \mathrm{~Hz}) ;{ }^{13} \mathrm{C}$ NMR $\left(100 \mathrm{MHz}, \mathrm{CDCl}_{3}\right) \delta 167.5,159.7,153.4,140.2$, 125.1, $118.6\left(\mathrm{q}, J_{\mathrm{C}-\mathrm{F}}=317 \mathrm{~Hz}\right), 113.0,112.9,92.8,67.9,56.8,45.5,31.5,29.9$; FTIR (neat) 2870, 1783, 1635, 1419, 1214, 1137, 957; LRMS (CI) calcd for $\left[\mathrm{C}_{14} \mathrm{H}_{14} \mathrm{~F}_{3} \mathrm{O}_{8} \mathrm{~S}\right]\left([\mathrm{MH}]^{+}\right) 399$; found 399; $[\alpha]_{\mathrm{D}}^{23}-94\left(c 0.8, \mathrm{CHCl}_{3}\right)$.

To a solution of ester obtained above $(59.5 \mathrm{mg}, 0.15 \mathrm{mmol})$ in $20 \mathrm{~mL}$ of $\mathrm{MeOH}$, Raney nickel (50\% slurry in water, pore size $\sim 50$, surface area $80-100 \mathrm{~m}^{2} / \mathrm{g}$, rinsed with $\mathrm{MeOH}$ ) was added as a slurry in $\mathrm{MeOH}(0.4 \mathrm{~mL})$. After stirring for $3 \mathrm{~h}$ under hydrogen at room temperature, the reaction mixture was filtered through a pad of Celite ${ }^{\circledR}$ and washed with $\mathrm{MeOH}(30 \mathrm{~mL})$. Purification by chromatography on silica gel (elution with 1:1 EtOAc/hexanes ) and vacuum sublimation $\left(120^{\circ} \mathrm{C}, 0.1 \mathrm{mmHg}\right)$ afforded $18.7 \mathrm{mg}(60 \%)$ of product 5 as a white solid. The physical and spectral data were identical to those previously reported for this compound ${ }^{6}: \mathrm{mp}$ $152-153^{\circ} \mathrm{C} ;{ }^{1} \mathrm{H}$ NMR $\left(400 \mathrm{MHz}, \mathrm{CDCl}_{3}\right) \delta 6.32(\mathrm{~d}, 1 \mathrm{H}, J=5.8 \mathrm{~Hz}), 6.04(\mathrm{~d}, 1 \mathrm{H}, J=2.0 \mathrm{~Hz})$, 5.90 (d, $1 \mathrm{H}, J=2.0 \mathrm{~Hz}), 4.09$ (m, $1 \mathrm{H}$ ), 3.99 (m, $1 \mathrm{H}$ ), 3.73 (s, $3 \mathrm{H}), 3.72-3.79$ (m, $1 \mathrm{H}), 3.63-$ $3.73(\mathrm{~m}, 1 \mathrm{H}), 2.10-2.20(\mathrm{~m}, 2 \mathrm{H}) ;{ }^{13} \mathrm{C} \mathrm{NMR}\left(100 \mathrm{MHz}, \mathrm{CDCl}_{3}\right) \delta 151.5,144.0,141.8,128.8$, 111.5, 103.1, 100.6, 67.5, 56.2, 47.7, 33.4; FTIR (neat) 3349, 2925, 2868, 1260, 1137, 957; LRMS (CI) calcd for $\left[\mathrm{C}_{11} \mathrm{H}_{13} \mathrm{O}_{4}\right]\left([\mathrm{MH}]^{+}\right) 209$; found 209; $[\alpha]_{D}^{23}-148\left(c 0.5, \mathrm{CHCl}_{3}\right)$.

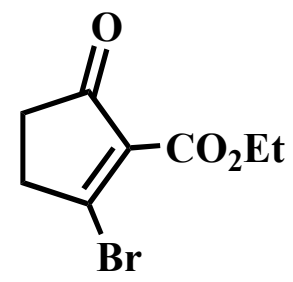

Ethyl 2-Bromo-5-oxocyclopent-1-enecarboxylate (6). Bromide 6 was prepared from methyl $t$ butyl succinate according to Büchi's method ${ }^{6}$. Recrystallization from ether-hexanes afforded 6 as a colorless crystal. The physical and spectral data were identical to those previously reported for this compound ${ }^{7}$ : $\mathrm{mp} 48.0-50.0{ }^{\circ} \mathrm{C} ;{ }^{1} \mathrm{H} \mathrm{NMR}\left(400 \mathrm{MHz}, \mathrm{CDCl}_{3}\right) \delta 4.35$ (q, $2 \mathrm{H}, J=7.2 \mathrm{~Hz}$ ),

\footnotetext{
${ }^{6}$ Noland, W.; Kedrowski, B. L. Org. Lett. 2000, 2, 2109-2111.

7 (a) Büchi, G.; Robert, E. C. J. Org. Chem. 1968, 33, 460-461. b) Büchi, G.; Weinreb, S. M. J. Am. Chem. Soc. 1971, 93, 746-752.
} 
$3.04(\mathrm{~m}, 2 \mathrm{H}), 2.63(\mathrm{~m}, 2 \mathrm{H}), 1.35(\mathrm{t}, 3 \mathrm{H}, J=7.2 \mathrm{~Hz}) ;{ }^{13} \mathrm{C} \mathrm{NMR}\left(100 \mathrm{MHz}, \mathrm{CDCl}_{3}\right) \delta$ 198.9, 163.4, 161.8, 137.9, 61.9, 36.8, 36.7, 14.3; FTIR (neat) 1715, 1615, 1366, 1278, 1195, 1023; LRMS (CI) calcd for $\left[\mathrm{C}_{8} \mathrm{H}_{10} \mathrm{BrO}_{3}\right]\left([\mathrm{MH}]^{+}\right) 233$; found 233.

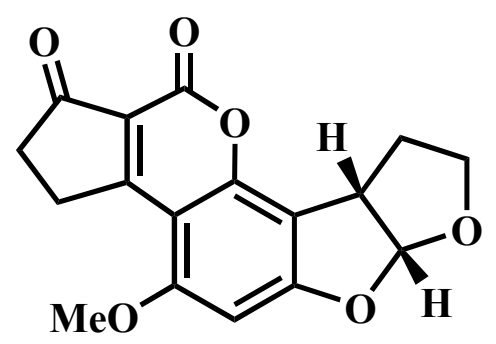

(-)-Aflatoxin $\mathbf{B}_{2}$ (1). To a suspension of a freshly ground mixture of $\mathrm{NaHCO}_{3}(1.0 \mathrm{~g})$ and $\mathrm{ZnCO}_{3}(0.6 \mathrm{~g})$ in $10 \mathrm{~mL}$ of $\mathrm{CH}_{2} \mathrm{Cl}_{2}$ was added vinyl bromide $6(40 \mathrm{mg}, 0.17 \mathrm{mmol})$ and compound 5 (18 $\mathrm{mg}, 0.086 \mathrm{mmol})$, the reaction mixture was stirred at room temperature for $20 \mathrm{~h}$. Then the reaction mixture was transferred to Soxhlet thimble and continuously extracted with $2 \% \mathrm{MeOH}-\mathrm{CH}_{2} \mathrm{Cl}_{2}$ for $24 \mathrm{~h}$. The solid left was dissolved in $10 \% \mathrm{HCl}$ and extracted with $\mathrm{CHCl}_{3}$. The combined extraction was washed with saturated aqueous $\mathrm{NaHCO}_{3}$ solution and dried over $\mathrm{Na}_{2} \mathrm{SO}_{4}$. The solvent was removed in vacuo and the residue was purified by chromatography on Florisil ( $1 \mathrm{~g}$, elution with $5 \% \mathrm{MeOH}$ in $\mathrm{CH}_{2} \mathrm{Cl}_{2}$ ) to give the aflatoxin $\mathrm{B}_{2}(\mathbf{1})$ as a white solid ( 9.7 $\mathrm{mg}, 36 \%$ ). The physical and spectral data were identical to those previously reported for natural aflatoxin $\mathrm{B}_{2}{ }^{7}$ : $\mathrm{mp} 300.0-301.0{ }^{\circ} \mathrm{C}$ (decomp), lit. ${ }^{8} \mathrm{mp}$ 300.0-303.0 ${ }^{\circ} \mathrm{C}$ (decomp); ${ }^{1} \mathrm{H}$ NMR (400 MHz, $\left.\mathrm{CDCl}_{3}\right) \delta 6.48(\mathrm{~d}, 1 \mathrm{H}, J=6.0 \mathrm{~Hz}), 6.33(\mathrm{~s}, 1 \mathrm{H}), 4.15(\mathrm{~m}, 2 \mathrm{H}), 3.94(\mathrm{~s}, 3 \mathrm{H}), 3.63(\mathrm{q}, 1 \mathrm{H}$, $J=8.8 \mathrm{~Hz}$ ), 3.40 (m, $2 \mathrm{H}), 2.63$ (m, $2 \mathrm{H}), 2.27$ (m, $2 \mathrm{H}) ;{ }^{13} \mathrm{C} \mathrm{NMR}\left(100 \mathrm{MHz}, \mathrm{CDCl}_{3}\right) \delta 201.6$, 177.3, 167.4, 161.9, 155.5, 153.6, 117.2, 114.1, 107.1, 104.0, 90.2, 68.1, 56.7, 44.2, 35.3, 31.8, 29.2; FTIR (neat) 1755, 1699, 1620, 1586, 1480, 1430, 1366, 949, 970; HRMS (CI) calcd for $\left[\mathrm{C}_{17} \mathrm{H}_{15} \mathrm{O}_{6}\right]\left([\mathrm{MH}]^{+}\right)$315.0868; found 315.0872; $[\alpha]_{\mathrm{D}}^{23}-428\left(c 0.1, \mathrm{CHCl}_{3}\right)$, lit. ${ }^{7}[\alpha]_{\mathrm{D}}^{23}-492(c$ $\left.0.1, \mathrm{CHCl}_{3}\right)$.

${ }^{8}$ (a) Roberts, J. C.; Sheppard, A. H.; Knight, J. A.; Roffery, P. J. Chem. Soc. (C) 1968, 22-24. (b) Merck Index, $12^{\text {th }}$, p33. (c)Horne, S.; Weeratunga, G.; Rodrigo, R. J. Chem. Soc., Chem. Commun. 1990, 39-41. 


\section{Part II. Enantioselective [3+2] reaction.}

Representative Procedure for the Preparation and Use of Chiral Oxazoborolidine Catalyst ${ }^{9}$.

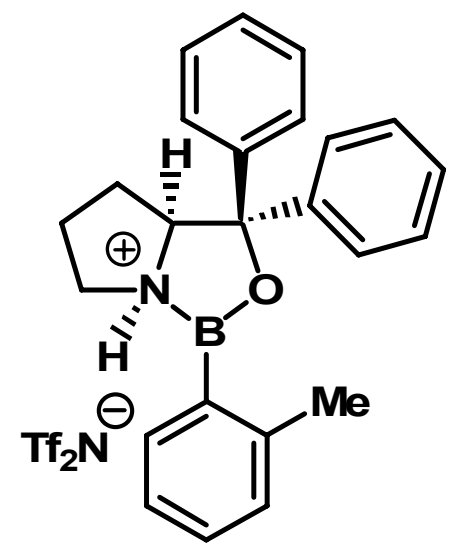

A $10 \mathrm{~mL}$ round-bottomed flask was fitted with a Dean-Stark apparatus that was charged with ca. $10 \mathrm{~g}$ of $4 \AA$ molecular sieves ${ }^{10}$. Tri-o-tolylboroxine (14.1 mg, $\left.0.04 \mathrm{mmol}\right),(S)$ - $\alpha, \alpha$-diphenyl2-pyrrolidinemethanol ${ }^{11}(30.2 \mathrm{mg}, 0.12 \mathrm{mmol})$ and toluene $(8 \mathrm{~mL})$ were added to the above flask. The resulting solution was stirred at room temperature for $30 \mathrm{~min}$, and heated to reflux (bath temperature $\sim 140{ }^{\circ} \mathrm{C}$ ). After $16 \mathrm{~h}$, the mixture was concentrated by removing solvent from the Dean-Stark apparatus, to a volume of $c a .1 \mathrm{~mL}$. The reaction mixture was cooled to room temperature, and the Dean-Stark apparatus was quickly replaced with a nitrogen inlet adaptor. Concentration in vacuo (ca. $0.1 \mathrm{mmHg}, 1 \mathrm{~h}$ ) afforded the corresponding oxazaborolidine as clear oil, which was then dissolved in $\mathrm{CH}_{2} \mathrm{Cl}_{2}$. To a solution of the oxazaborolidine $(0.12 \mathrm{mmol}$, theoretical) in $1 \mathrm{~mL}$ of $\mathrm{CH}_{2} \mathrm{Cl}_{2}$ at $-20{ }^{\circ} \mathrm{C}$ was added dropwise trifluoromethanesulfonimide $(0.50$ $\mathrm{M}$ solution in $\mathrm{CH}_{2} \mathrm{Cl}_{2}$, freshly prepared, $0.2 \mathrm{~mL}, 0.10 \mathrm{mmol}$ ). After $15 \mathrm{~min}$ at $-20{ }^{\circ} \mathrm{C}$, a colorless homogeneous catalyst ent-A solution was ready for further reaction use.

9 (a) Corey, E. J.; Shibata, T.; Lee, T. W. J. Am. Chem. Soc. 2002, 124, 3808-3809. (b) Ryu, D. H.; Lee, T. W.; Corey, E. J. J. Am. Chem. Soc. 2002, 124, 9992-9993. (c) Ryu, D. H.; Corey, E. J. J. Am. Chem. Soc. 2003, 125, 6388-6390. (d) Ryu, D. H.; Zhou, G. ; Corey, E. J. J. Am. Chem. Soc. 2004, 126, 13708-13713.

${ }_{10}$ Molecular sieves (pellets) were dried in vacuo at ca. $200{ }^{\circ} \mathrm{C}$ with a gas burner for 10 min prior to use.

11 Purchased from Sigma-Aldrich Co. and used without further purification. 
The pre-mixed solution of 2-methoxy-1,4-benzoquinone $(69 \mathrm{mg}, 0.5 \mathrm{mmol})$ and dihydrofuran $(52.5 \mathrm{mg}, 0.75 \mathrm{mmol})$ in anhydrous $\mathrm{CH}_{3} \mathrm{CN}\left(1: 1\right.$ to $\left.\mathrm{CH}_{2} \mathrm{Cl}_{2}\right)$ was added to the catalyst ent-A solution dropwise during $1 \mathrm{~h}$ by syringe pump. The reaction mixture was then allowed to warm to room temperature slowly for $5 \mathrm{~h}$. After the reaction was complete, $\mathrm{MeOH}$ $(0.2 \mathrm{~mL})$ and $\mathrm{H}_{2} \mathrm{O}(3 \mathrm{~mL})$ were added to the reaction mixture. The aqueous layer was extracted with $\mathrm{CH}_{2} \mathrm{Cl}_{2}(4 \times 20 \mathrm{~mL})$. The combined organic laywers were washed with water, brine and dried over $\mathrm{Na}_{2} \mathrm{SO}_{4}$. After concentration in vacuo, the residue was purified by chromatography on silica gel to give the (+)-2,3,3aR,8aS-tetrahydro-5-hydroxy-6-methoxy[2,3-d]-benzo[b]furan (67. 6mg, 65\%) and (+)-2,3,3aR,8aS-tetrahydro-5-hydroxy-7-methoxy[2,3-d]-benzo[b]furan (33.3 mg, 32\%) compound as white solid.

\section{Determination of Diastereoselectivity, Enantioselectivity and Absolute Configuration of the Compounds Reported in Tables.}

Table 1, entry 1: Enantioselectivity of 7 was determined by GC analysis using a $\mathrm{J} \& \mathrm{~W}$ Scientific Cyclosil-B column $\left(30 \mathrm{~m} \times 0.25 \mathrm{~mm}, 170{ }^{\circ} \mathrm{C}, 25 \mathrm{psi}\right)$; retention times: $31.9 \mathrm{~min}$ (minor), $33.1 \mathrm{~min}$ (major). The absolute configuration of 7 was assigned by X-ray crystallographic analysis of (-)-2,3,3aS,8aR-tetrahydro-5-(4-bromobenzyl)-6-methoxy-[2,3- $d$ ]benzo[b]furan.

Table 1, entry 2: Enantioselectivity was determined by GC analysis using a $\gamma$-TA column (170 ${ }^{\circ} \mathrm{C}, 22 \mathrm{psi}$ ); retention times: $30.5 \mathrm{~min}$ (major), $33.2 \mathrm{~min}$ (minor). The absolute configuration was determined by X-ray analysis and analogy with (+)-2,3,3aR,8aS-tetrahydro-5hydroxy-6-methoxy[2,3-d]-benzo[b]furan.

Table 1, entry 3: Diastereoselectivity (regioselectivity) was determined by ${ }^{1} \mathrm{H}$ NMR analysis of the crude mixture: $\delta 6.27(\mathrm{~d}, 1 \mathrm{H}, J=8.4 \mathrm{~Hz}$ ) (minor), 3.08 (dd, $1 \mathrm{H}, J=11.6,5.6 \mathrm{~Hz}$ ) (major). Enantioselectivity was determined by GC analysis using a J \& W Scientific Cyclosil-B column 
$\left(30 \mathrm{~m} \times 0.25 \mathrm{~mm}, 160{ }^{\circ} \mathrm{C}, 25 \mathrm{psi}\right.$ ); retention times: $51.6 \mathrm{~min}$ (minor), $52.8 \mathrm{~min}$ (minor). The absolute configuration was determined by analogy with (+)-2,3,3aR,8aS-tetrahydro-5-hydroxy6-methoxy[2,3-d]-benzo[b]furan.

Table 1, entry 4: Diastereoselectivity (regioselectivity) was determined by ${ }^{1} \mathrm{H}$ NMR analysis of the crude mixture: $\delta 6.25(\mathrm{~d}, 1 \mathrm{H}, J=5.6 \mathrm{~Hz})($ major), $6.34(\mathrm{~d}, 1 \mathrm{H}, J=6.0 \mathrm{~Hz})$ (minor). Enantioselectivity was determined by GC analysis using a $\gamma$-TA column $\left(160{ }^{\circ} \mathrm{C}, 22 \mathrm{psi}\right)$; retention times: $28.7 \mathrm{~min}$ (minor), $29.8 \mathrm{~min}$ (major). The absolute configuration was determined by analogy with (+)-2,3,3aR,8aS-tetrahydro-5-hydroxy-6-methoxy[2,3-d]-benzo[b]furan.

Table 1, entry 5: Enantioselectivity was determined by GC analysis using a J \& W Scientific Cyclosil-B column $\left(30 \mathrm{~m} \times 0.25 \mathrm{~mm}, 180{ }^{\circ} \mathrm{C}, 25 \mathrm{psi}\right)$; retention times: 27.4 min (major), 29.3 min (minor). The absolute configuration was determined by analogy with (+)-2,3,3aR,8aStetrahydro-5-hydroxy-6-methoxy[2,3-d]-benzo[b]furan.

Compound 9: Enantioselectivity was determined by HPLC analysis using a Chiralcel OD-H column ( $1 \% i-\mathrm{PrOH}$ in hexanes for elution; $1 \mathrm{~mL} / \mathrm{min} ; \lambda 254 \mathrm{~nm}$ ): retention times: 18.9 min (major), 21.9 min (minor). The absolute configuration was determined by analogy with (+)-2, 3, $3 a R, 8 a S$-tetrahydro-5-hydroxy-6-methoxy[2, 3- $d]$-benzo[b]furan.

Compound 10: Enantioselectivity was determined by HPLC analysis using a Chiralcel OD-H column ( $0.5 \% i$-PrOH in hexanes for elution; $1 \mathrm{~mL} / \mathrm{min} ; \lambda 254 \mathrm{~nm}$ ); retention times: $35.2 \mathrm{~min}$ (minor), $55.8 \mathrm{~min}$ (major). The relative configuration was determined by NOE experiment.

\section{Experimental Procedures and Physical Data of the Products:}

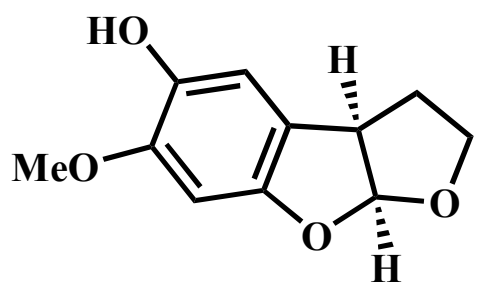


(+)-2,3,3aR,8aS-Tetrahydro-5-hydroxy-6-methoxy[2,3-d]-benzo[b]furan (Table 1, entry 1).

Purification by chromatography on silica gel (elution with 1:1 ether/hexanes) afforded $67.6 \mathrm{mg}$ $(65 \%)$ of $(+)-2,3,3 a R, 8 a S$-tetrahydro-5-hydroxy-6-methoxy[2,3- $d]$-benzo[b]furan as a white solid. The IR, ${ }^{1} \mathrm{H}$ NMR and ${ }^{13} \mathrm{C}$ NMR spectra were identical to those of the compound obtained with $(R)$-catalyst $\mathrm{A}: \operatorname{mp} 151-152{ }^{\circ} \mathrm{C} ;{ }^{1} \mathrm{H}$ NMR $\left(400 \mathrm{MHz}, \mathrm{CDCl}_{3}\right) \delta 6.74(\mathrm{~d}, 1 \mathrm{H}, J=0.8 \mathrm{~Hz}$ ), $6.41(\mathrm{~s}, 1 \mathrm{H}), 6.25(\mathrm{~d}, 1 \mathrm{H}, J=6.4 \mathrm{~Hz}), 5.26(\mathrm{~s}, 1 \mathrm{H}, \mathrm{OH}), 4.04(\mathrm{t}, 1 \mathrm{H}, J=8.0 \mathrm{~Hz}), 3.94(\mathrm{dd}, 1 \mathrm{H}$, $J=7.8,6.0 \mathrm{~Hz}$ ), $3.84(\mathrm{~s}, 3 \mathrm{H}), 3.57-3.63(\mathrm{~m}, 1 \mathrm{H}), 2.18-2.28(\mathrm{~m}, 1 \mathrm{H}), 2.01(\mathrm{dd}, 1 \mathrm{H}, J=12.0$, $4.8 \mathrm{~Hz}) ;{ }^{13} \mathrm{C} \mathrm{NMR}\left(100 \mathrm{MHz}, \mathrm{CDCl}_{3}\right) \delta 153.0,146.9,140.4,118.5,111.5,110.3,93.9,67.5,56.4$, 47.1, 33.7; FTIR (neat) 3049, 2925, 2854, 1497, 1158, 957; LRMS (CI) calcd for $\left[\mathrm{C}_{11} \mathrm{H}_{13} \mathrm{O}_{4}\right]$ $\left([\mathrm{MH}]^{+}\right) 209 ;$ found $209 ;[\alpha]_{\mathrm{D}}^{23}+88\left(c 0.9, \mathrm{CHCl}_{3}, 92 \% e e\right)$.

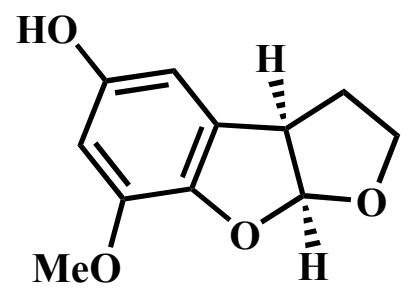

(+)-2,3,3aR,8aS-Tetrahydro-5-hydroxy-7-methoxy[2,3-d]-benzo[b]furan (Table 1, entry 1). Purification by chromatography on silica gel (elution with $2: 1 \mathrm{Et}_{2} \mathrm{O} /$ hexanes) afforded $33.3 \mathrm{mg}$ (32\%) of (+)-2,3,3aR,8aS-tetrahydro-5-hydroxy-7-methoxy[2,3- $d]$-benzo[b]furan as a white solid. Enantioselectivity was determined by GC analysis using a J \& W Scientific Cyclosil-B column $\left(30 \mathrm{~m} \times 0.25 \mathrm{~mm}, 170{ }^{\circ} \mathrm{C}, 25 \mathrm{psi}\right)$; retention times: $51.8 \mathrm{~min}$ (minor), $54.9 \mathrm{~min}$ (major). The absolute configuration was assigned by X-ray crystallographic analysis and analogy with (+)2,3,3aR,8aS-tetrahydro-5-hydroxy-6-methoxy[2,3-d]-benzo[b]furan: mp 150-152 ${ }^{\circ} \mathrm{C} ;{ }^{1} \mathrm{H}$ NMR $\left(400 \mathrm{MHz}, \mathrm{CDCl}_{3}\right) \delta 6.30(\mathrm{~m}, 2 \mathrm{H}), 6.28(\mathrm{~d}, 1 \mathrm{H}, J=1.2 \mathrm{~Hz}), 4.69(\mathrm{~s}, 1 \mathrm{H}), 4.06(\mathrm{t}, 1 \mathrm{H}, J=8.4$ Hz), 3.93 (dd, $1 \mathrm{H}, J=12.0,8.4 \mathrm{~Hz}), 3.80$ (s, $3 \mathrm{H}), 3.59-3.65$ (m, $1 \mathrm{H}), 2.18-2.28$ (m, $1 \mathrm{H}), 2.02$ (dd, $1 \mathrm{H}, J=16.4,6.8 \mathrm{~Hz}$ ); FTIR (neat) 3357, 2975, 2846, 1629, 1495, 1345, 1065, 943; LRMS (CI) calcd for $\left[\mathrm{C}_{11} \mathrm{H}_{13} \mathrm{O}_{4}\right]\left([\mathrm{MH}]^{+}\right) 209$; found 209; $[\alpha]_{\mathrm{D}}^{23}+93$ (c 2.0, $\mathrm{CHCl}_{3}, 90 \%$ ee $)$. 


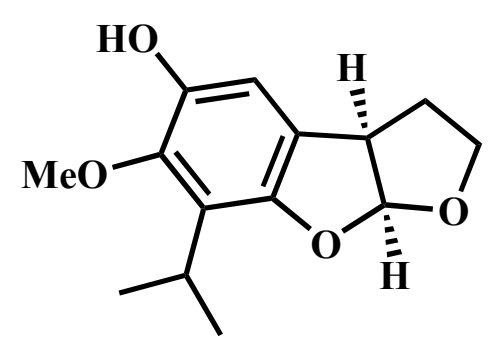

\section{(+)-2,3,3aR,8aS-Tetrahydro-5-hydroxy-6-methoxy-7-isopropyl-[2,3-d]-benzo[b]furan}

(Table 2, entry 2). Purification by chromatography on silica gel (elution 1:2 ether/hexanes) afforded $93.7 \mathrm{mg}(75 \%)$ of (+)-2,3,3aR,8aS-tetrahydro-5-hydroxy-6-methoxy-7-isopropyl-[2,3d]-benzo[b]furan as a colorless solid: $\mathrm{mp} 109-111^{\circ} \mathrm{C} ;{ }^{1} \mathrm{H} \mathrm{NMR}\left(400 \mathrm{MHz}, \mathrm{CDCl}_{3}\right) \delta 6.64(\mathrm{~d}, 1 \mathrm{H}$, $J=0.8 \mathrm{~Hz}), 6.26(\mathrm{~d}, 1 \mathrm{H}, J=5.6 \mathrm{~Hz}), 5.24(\mathrm{~s}, 1 \mathrm{H}, \mathrm{OH}), 4.03(\mathrm{t}, 1 \mathrm{H}, J=8.0 \mathrm{~Hz}), 3.89(\mathrm{~m}, 1 \mathrm{H})$, $3.75(\mathrm{~s}, 3 \mathrm{H}), 3.56(\mathrm{~m}, 1 \mathrm{H}), 3.24(\mathrm{~m}, 1 \mathrm{H}), 2.22(\mathrm{~m}, 1 \mathrm{H}), 2.00(\mathrm{dd}, 1 \mathrm{H}, J=8.0,4.8 \mathrm{~Hz}), 1.34$ (d, $3 \mathrm{H}, J=2.0 \mathrm{~Hz}), 1.32(\mathrm{~d}, 3 \mathrm{H}, J=2.0 \mathrm{~Hz}) ;{ }^{13} \mathrm{C} \mathrm{NMR}\left(100 \mathrm{MHz}, \mathrm{CDCl}_{3}\right) \delta 151.7,144.3,143.6$, 123.73, 123.69, 110.9, 108.3, 67.2, 62.3, 46.7, 33.8, 25.9, 21.2, 21.0; FTIR (neat) 3393, 2958, 2873, 1453, 1341, 1025, 955; LRMS (CI) calcd for $\left[\mathrm{C}_{14} \mathrm{H}_{19} \mathrm{O}_{4}\right]\left([\mathrm{MH}]^{+}\right) 251$; found 251; $[\alpha]_{\mathrm{D}}^{23}$ +110 (c $0.8, \mathrm{CHCl}_{3}, 95 \%$ ee); The configuration was determined by X-ray crystallographic analysis.

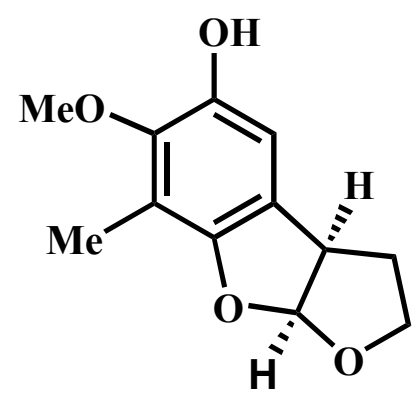

(+)-2,3,3aR,8aS-Tetrahydro-5-hydroxy-6-methoxy-7-methyl-[2,3-d]-benzo[b]furan (Table 2, entry 3). Purification by chromatography on silica gel (1:10 EtOAc/hexanes) afforded $94.5 \mathrm{mg}$ $(68 \%)$ of (+)-2,3,3aR,8aS-tetrahydro-5-hydroxy-6-methoxy-7-methyl-[2,3- $d]$-benzo[b]furan as a

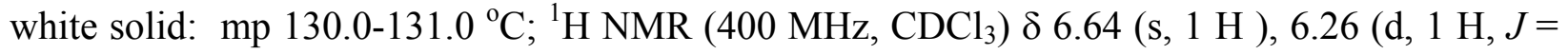
$5.2 \mathrm{~Hz}), 5.25$ (brs, $1 \mathrm{H}, \mathrm{OH}), 4.04$ (t, $1 \mathrm{H}, J=8.0 \mathrm{~Hz}), 3.93(\mathrm{dt}, 1 \mathrm{H}, J=5.2,2.4 \mathrm{~Hz}), 3.77$ (s, 3 $\mathrm{H}), 3.60-3.65(\mathrm{~m}, 1 \mathrm{H}), 2.10-2.26(\mathrm{~m}, 1 \mathrm{H}), 2.18(\mathrm{~s}, 3 \mathrm{H}), 2.03(\mathrm{dd}, 1 \mathrm{H}, J=12.0,4.8 \mathrm{~Hz}) ;{ }^{13} \mathrm{C}$ 
NMR $\left(100 \mathrm{MHz}, \mathrm{CDCl}_{3}\right) \delta 151.9,145.5,143.6,122.2,112.9,111.0,108.1,67.5,61.2,47.4$, 33.6, 9.8; FTIR (neat) 2952, 1462, 1427, 1246, 1109, 1056, 958, 837; LRMS (CI) calcd for $\left[\mathrm{C}_{12} \mathrm{H}_{15} \mathrm{O}_{4}\right]\left([\mathrm{MH}]^{+}\right) 223$; found 223; $[\alpha]_{\mathrm{D}}^{23}+132\left(c 0.5, \mathrm{CHCl}_{3}, 95 \% e e\right)$.

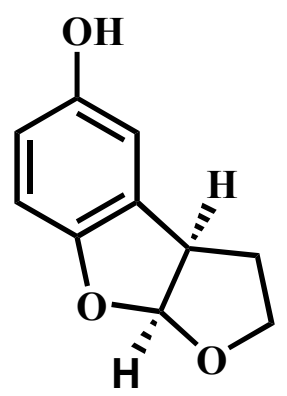

(+)-2,3,3aR,8aS-Tetrahydro-5-hydroxyl-[2,3-d]-benzo[b]furan (Table 2, entry 4). Purification by chromatography on silica gel (1:10 EtOAc/hexanes) afforded $56 \mathrm{mg}(63 \%)$ of product as a white solid: $\mathrm{mp} 111.0-112.0{ }^{\circ} \mathrm{C} ;{ }^{1} \mathrm{H} \mathrm{NMR}\left(400 \mathrm{MHz}, \mathrm{CDCl}_{3}\right) \delta 6.70(\mathrm{~d}, 1 \mathrm{H}, J=2.4$ $\mathrm{Hz}$ ), $6.63(\mathrm{AB}, 2 \mathrm{H}, J=8.4,2.4 \mathrm{~Hz}), 6.28(\mathrm{~d}, 1 \mathrm{H}, J=5.6 \mathrm{~Hz}), 4.75(\mathrm{~s}, 1 \mathrm{H}, \mathrm{OH}), 4.07$ (t, $1 \mathrm{H}, J$ $=8.4 \mathrm{~Hz}), 3.97(\mathrm{t}, 1 \mathrm{H}, J=8.0,2.8 \mathrm{~Hz}), 3.58-3.67(\mathrm{~m}, 1 \mathrm{H}), 2.21-2.34(\mathrm{~m}, 1 \mathrm{H}), 2.04(\mathrm{dd}, 1 \mathrm{H}, J$ $=16.4,6.8 \mathrm{~Hz}) ;{ }^{13} \mathrm{C} \mathrm{NMR}\left(100 \mathrm{MHz}, \mathrm{CDCl}_{3}\right) \delta 153.7,150.4,128.9,115.4,112.1,111.3,109.6$, 67.5, 47.2, 33.6; FTIR (neat) 3365, 2979, 1490, 1459, 1246, 1191, 959, 854; LRMS (CI) calcd for $\left[\mathrm{C}_{10} \mathrm{H}_{11} \mathrm{O}_{3}\right]\left([\mathrm{MH}]^{+}\right) 179$; found $179 ;[\alpha]_{D}^{23}+65\left(c 0.4, \mathrm{CHCl}_{3}, 91 \% e e\right)$.

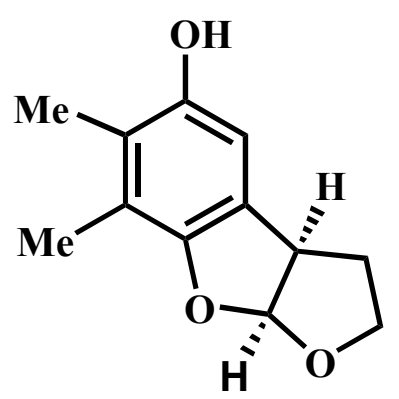

$(+)-2,3,3 a R, 8 a S$-Tetrahydro-5-hydroxy-6,7-dimethyl-[2,3-d]-benzo[b]furan (Table 2, entry 5). Purification by chromatography on silica gel (1:20 EtOAc/hexanes) afforded $84.5 \mathrm{mg}(82 \%)$ of (+)-2,3,3aR,8aS-tetrahydro-5-hydroxy-6,7-dimethyl-[2,3-d]-benzo[b]furan as a white solid: mp 148.0-150.0 ${ }^{\circ} \mathrm{C} ;{ }^{1} \mathrm{H}$ NMR (400 MHz, $\left.\mathrm{CDCl}_{3}\right) \delta 6.51(\mathrm{~s}, 1 \mathrm{H}), 6.26(\mathrm{~d}, 1 \mathrm{H}, J=5.6 \mathrm{~Hz}), 4.53$ (s, $1 \mathrm{H}, \mathrm{OH}), 4.04(\mathrm{t}, 1 \mathrm{H}, J=8.4 \mathrm{~Hz}), 3.95(\mathrm{t}, 1 \mathrm{H}, J=6.4 \mathrm{~Hz}), 3.58-3.65(\mathrm{~m}, 1 \mathrm{H}), 2.19-2.28(\mathrm{~m}$, 
$1 \mathrm{H}), 2.15(\mathrm{~s}, 3 \mathrm{H}), 2.12(\mathrm{~s}, 3 \mathrm{H}), 2.01(\mathrm{dd}, 1 \mathrm{H}, J=12.4,4.8 \mathrm{~Hz}) ;{ }^{13} \mathrm{C}$ NMR $\left(100 \mathrm{MHz}, \mathrm{CDCl}_{3}\right)$ $\delta 152.4,148.3,124.2,123.1,119.0,110.5,108.7,67.4,47.5,33.7,12.7,12.0$; FTIR (neat) 2962, 2927, 1457, 1208, 972; LRMS (CI) calcd for $\left[\mathrm{C}_{12} \mathrm{H}_{15} \mathrm{O}_{3}\right]\left([\mathrm{MH}]^{+}\right) 207$; found 207; $[\alpha]_{\mathrm{D}}^{23}+93(c$ $\left.1.9, \mathrm{CHCl}_{3}, 98 \% e e\right)$.

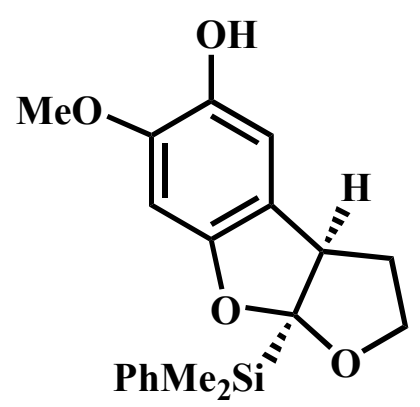

$(-)-2,3,3 a R, 8 a R$-Tetrahydro-5-hydroxy-6-methoxy-[2,3-d]-benzo[b]furan (9). Purification by chromatography on silica gel (1:20 EtOAc/hexanes) afforded $123 \mathrm{mg}(72 \%)$ of 9 as a white solid: mp 109.0-110.0 ${ }^{\circ} \mathrm{C} ;{ }^{1} \mathrm{H}$ NMR (400 MHz, $\left.\mathrm{CDCl}_{3}\right) \delta 7.62$ (m, $2 \mathrm{H}$ ), $7.36(\mathrm{~m}, 3 \mathrm{H}), 6.66(\mathrm{~d}, 1$ $\mathrm{H}, J=0.4 \mathrm{~Hz}), 6.42(\mathrm{~s}, 1 \mathrm{H}), 5.19(\mathrm{~s}, 1 \mathrm{H}, \mathrm{OH}), 3.98(\mathrm{t}, 1 \mathrm{H}, J=8.0 \mathrm{~Hz}), 3.83(\mathrm{~s}, 3 \mathrm{H}), 3.75(\mathrm{~d}, 1$ $\mathrm{H}, J=7.6 \mathrm{~Hz}), 3.53-3.59(\mathrm{~m}, 1 \mathrm{H}), 1.90(\mathrm{dd}, 1 \mathrm{H}, J=15.6,6.4 \mathrm{~Hz}), 1.75-1.85(\mathrm{~m}, 1 \mathrm{H}), 0.44(\mathrm{~s}$, $3 \mathrm{H}), 0.39$ (s, $3 \mathrm{H}) ;{ }^{13} \mathrm{C} \mathrm{NMR}\left(100 \mathrm{MHz}, \mathrm{CDCl}_{3}\right) \delta$ 154.0, 146.7, 140.0, 135.2, 134.6(2 C), 129.8, 128.0(2 C), 119.3, 118.9, 110.1, 93.8, 68.0, 56.3, 50.2, 35.0, -5.6, -5.9; FTIR (neat) 3211, 2964 , 2873, 1493, 1246, 1156, 1113, 808, 734; LRMS (CI) calcd for $\left[\mathrm{C}_{19} \mathrm{H}_{23} \mathrm{O}_{4} \mathrm{Si}\right]\left([\mathrm{MH}]^{+}\right) 343$; found $343 ;[\alpha]_{\mathrm{D}}^{23}-50\left(c 3.7, \mathrm{CHCl}_{3}, 89 \% e e\right)$.

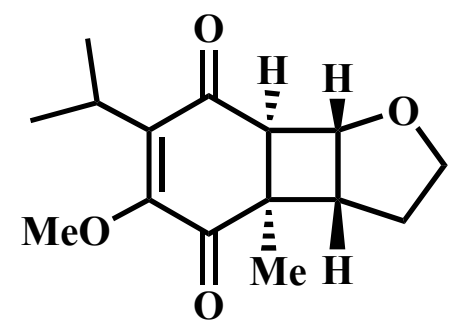

(-)- 10. To a solution of $(S)$-catalyst ent-A $(0.10 \mathrm{mmol})$ in $2.5 \mathrm{~mL}$ of $\mathrm{CH}_{2} \mathrm{Cl}_{2}$ at $-78{ }^{\circ} \mathrm{C}$, 2isopropyl-3-methoxy-5-methyl-1,4-benzoquinone $(97 \mathrm{mg}, 0.5 \mathrm{mmol})$ and dihydrofuran $(140 \mathrm{mg}$, $2 \mathrm{mmol}$ ) in $2.5 \mathrm{ml}$ of anhydrous $\mathrm{CH}_{3} \mathrm{CN}$ were added in one portion. The reaction mixture was then allowed to warm to room temperature slowly for $48 \mathrm{~h}$. After the reaction was complete, 
$\mathrm{MeOH}(1 \mathrm{~mL})$ and $\mathrm{H}_{2} \mathrm{O}(5 \mathrm{~mL})$ were added to the reaction mixture. The aqueous layer was extracted with $\mathrm{CH}_{2} \mathrm{Cl}_{2}(4 \times 20 \mathrm{~mL})$. The combined organic layers were washed with water, brine and dried over $\mathrm{Na}_{2} \mathrm{SO}_{4}$. After concentration in vacuo, the residue was purified by chromatography on silica gel (elution with $3: 2$ ether/hexanes) to give $\mathbf{1 0}(33 \mathrm{mg}, 25 \%)$ as a yellow oil: ${ }^{1} \mathrm{H}$ NMR (400 MHz, $\left.\mathrm{CDCl}_{3}\right) \delta 4.51(\mathrm{dd}, 1 \mathrm{H}, J=6.4,3.2 \mathrm{~Hz}), 4.21(\mathrm{dt}, 1 \mathrm{H}, J=9.2$, $0.8 \mathrm{~Hz}$ ), 3.91 (s, $3 \mathrm{H}), 3.79-3.85(\mathrm{~m}, 1 \mathrm{H}), 3.21$ (quin, $1 \mathrm{H}, J=6.8 \mathrm{~Hz}), 3.12$ (t, $1 \mathrm{H}, J=8.0 \mathrm{~Hz}$ ), $2.91(\mathrm{~d}, 1 \mathrm{H}, J=3.6 \mathrm{~Hz}), 2.00(\mathrm{dt}, 1 \mathrm{H}, J=13.6,6.0 \mathrm{~Hz}), 1.87-1.90(\mathrm{~m}, 1 \mathrm{H}), 1.23(\mathrm{~s}, 3 \mathrm{H}), 1.20$ $(\mathrm{d}, 3 \mathrm{H}, J=1.2 \mathrm{~Hz}), 1.18$ (d, $3 \mathrm{H}, J=1.2 \mathrm{~Hz}) ;{ }^{13} \mathrm{C} \mathrm{NMR}\left(100 \mathrm{MHz}, \mathrm{CDCl}_{3}\right) \delta 198.2,196.0,143.9$, 79.3, 68.5, 59.95, 59.97, 57.2, 45.5, 43.4, 26.1, 25.7, 20.2, 20.1, 19.0; FTIR (neat) 2959, 1658, 1587, 1270, 1065, 968; LRMS (CI) calcd for $\left[\mathrm{C}_{15} \mathrm{H}_{21} \mathrm{O}_{4}\right]\left([\mathrm{MH}]^{+}\right) 265$; found 265; $[\alpha]_{\mathrm{D}}^{23}-24(c$ $1.2, \mathrm{CHCl}_{3}, 99 \%$ ee).

Part III. Mechanism Study.
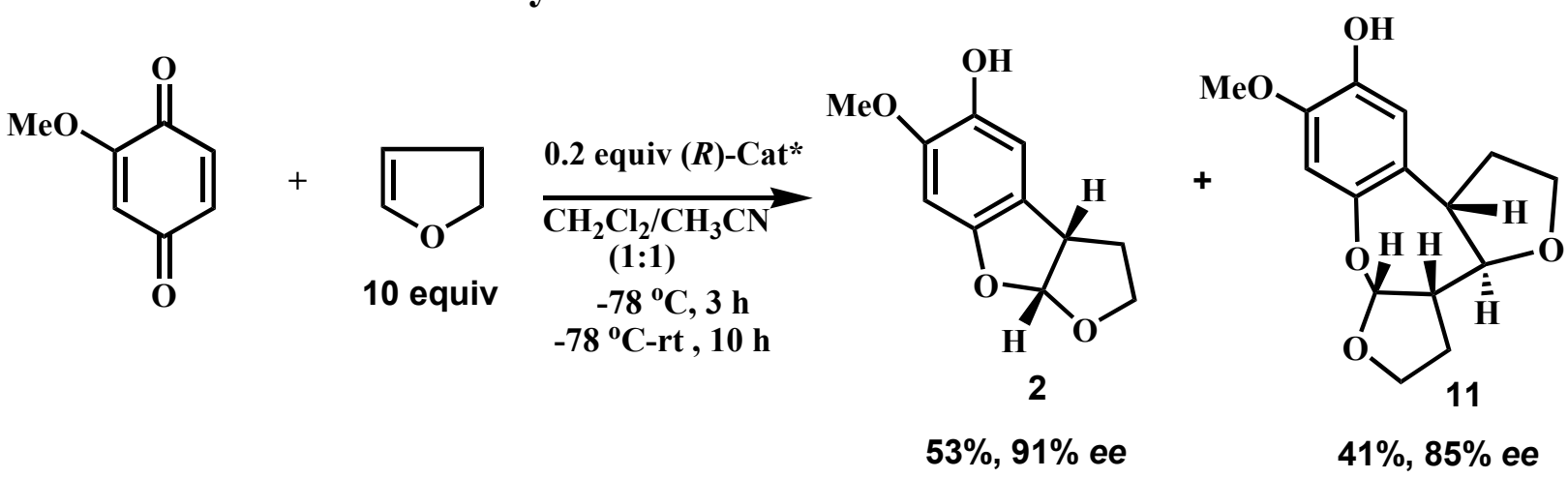

To a solution of $(R)$-catalyst $\mathbf{A}(0.10 \mathrm{mmol})$ in $2.5 \mathrm{~mL}$ of $\mathrm{CH}_{2} \mathrm{Cl}_{2}$ at $-78{ }^{\circ} \mathrm{C}, 2$-methoxy-1,4benzoquinone (69 $\mathrm{mg}, 0.5 \mathrm{mmol})$ and dihydrofuran $(350 \mathrm{mg}, 5 \mathrm{mmol}$ ) in $2.5 \mathrm{ml}$ of anhydrous $\mathrm{CH}_{3} \mathrm{CN}$ was added to the catalyst solution dropwise during $3 \mathrm{~h}$ by syringe pump. The reaction mixture was then allowed to warm to room temperature slowly for $10 \mathrm{~h}$. After the reaction was complete, $\mathrm{MeOH}(1 \mathrm{ml})$ and $\mathrm{H}_{2} \mathrm{O}(5 \mathrm{ml})$ were added to the reaction mixture. The aqueous layer was extracted with $\mathrm{CH}_{2} \mathrm{Cl}_{2}(4 \times 20 \mathrm{~mL})$. The combined organic layers were washed with water, brine, and dried over $\mathrm{Na}_{2} \mathrm{SO}_{4}$. After concentration in vacuo, the residue was purified by chromatography on silica gel (elution with $1: 1$ to $3: 2$ ether/hexanes) to give the (-)-2,3,3aS,8aR- 
tetrahydro-5-hydroxy-6-methoxy[2,3-d]-benzo[b]furan (2) $(55.1 \mathrm{mg}, 53 \%)$ and (-)-11 (57 mg, 41\%) as a white solid. Enantioselectivity of 11 was determined by conversion to the (R)-MTPA ester derivative and ${ }^{1} \mathrm{H}$ NMR integration (400 MHz, $\mathrm{CDCl}_{3}$ ): $\delta 5.54(\mathrm{~d}, 1 \mathrm{H}, J=4.8 \mathrm{~Hz}$ ) (major), $5.21\left(\mathrm{~d}, 1 \mathrm{H}, J=4.4 \mathrm{~Hz}\right.$ ) (minor); ${ }^{19} \mathrm{~F}$ NMR integration (376.2 $\left.\mathrm{MHz}, \mathrm{CDCl}_{3}\right): \delta-72.14\left(\mathrm{~s}, \mathrm{CF}_{3}\right)$ (major), $-72.23\left(\mathrm{~s}, \mathrm{CF}_{3}\right)$ (minor). The absolute configuration was determined by X-ray analysis: mp 45.0-46.0 ${ }^{\circ} \mathrm{C} ;{ }^{1} \mathrm{H}$ NMR (400 MHz, $\left.\mathrm{CDCl}_{3}\right) \delta 6.66(\mathrm{~d}, 1 \mathrm{H}, J=1.2 \mathrm{~Hz}), 6.53(\mathrm{~s}, 1 \mathrm{H}), 5.55$ (brs, $1 \mathrm{H}, \mathrm{OH}), 5.45(\mathrm{~d}, 1 \mathrm{H}, J=4.4 \mathrm{~Hz}), 4.37$ (dt, $1 \mathrm{H}, J=8.8,2.8 \mathrm{~Hz}), 3.95-4.01(\mathrm{~m}, 3 \mathrm{H}), 3.86$ $(\mathrm{dd}, 1 \mathrm{H}, J=10.8,8.4 \mathrm{~Hz}), 3.78(\mathrm{~s}, 3 \mathrm{H}), 3.28$ (q, $1 \mathrm{H}, J=8.0 \mathrm{~Hz}), 2.46-2.55(\mathrm{~m}, 2 \mathrm{H}), 2.30-2.38$ $(\mathrm{m}, 1 \mathrm{H}), 2.05$ (quart, $1 \mathrm{H}, J=10.0 \mathrm{~Hz}$ ), 1.96 (quart, $1 \mathrm{H}, J=10.0 \mathrm{~Hz}$ ); ${ }^{13} \mathrm{C} \mathrm{NMR}(100 \mathrm{MHz}$, $\left.\mathrm{CDCl}_{3}\right) \delta 147.6,145.7,141.6,121.8,114.7,106.6,104.6,82.7,70.6,67.4,56.2,50.9,46.2,33.4$, 29.1; FTIR (neat) 3419, 2937, 1629, 1506, 1445, 1194, 958; LRMS (CI) calcd for $\left[\mathrm{C}_{15} \mathrm{H}_{19} \mathrm{O}_{5}\right]$ $\left([\mathrm{MH}]^{+}\right) 279$; found $279 ;[\alpha]_{\mathrm{D}}^{23}-61\left(c 1.5, \mathrm{CHCl}_{3}, 85 \%\right.$ ee $)$. 


\section{Part IV. X-ray Structures.}

X-ray Structure of (-)-2,3,3aS,8aR-Tetrahydro-5-(4-bromobenzyl)-6-methoxy-[2,3-d]benzo $[b]$ furan
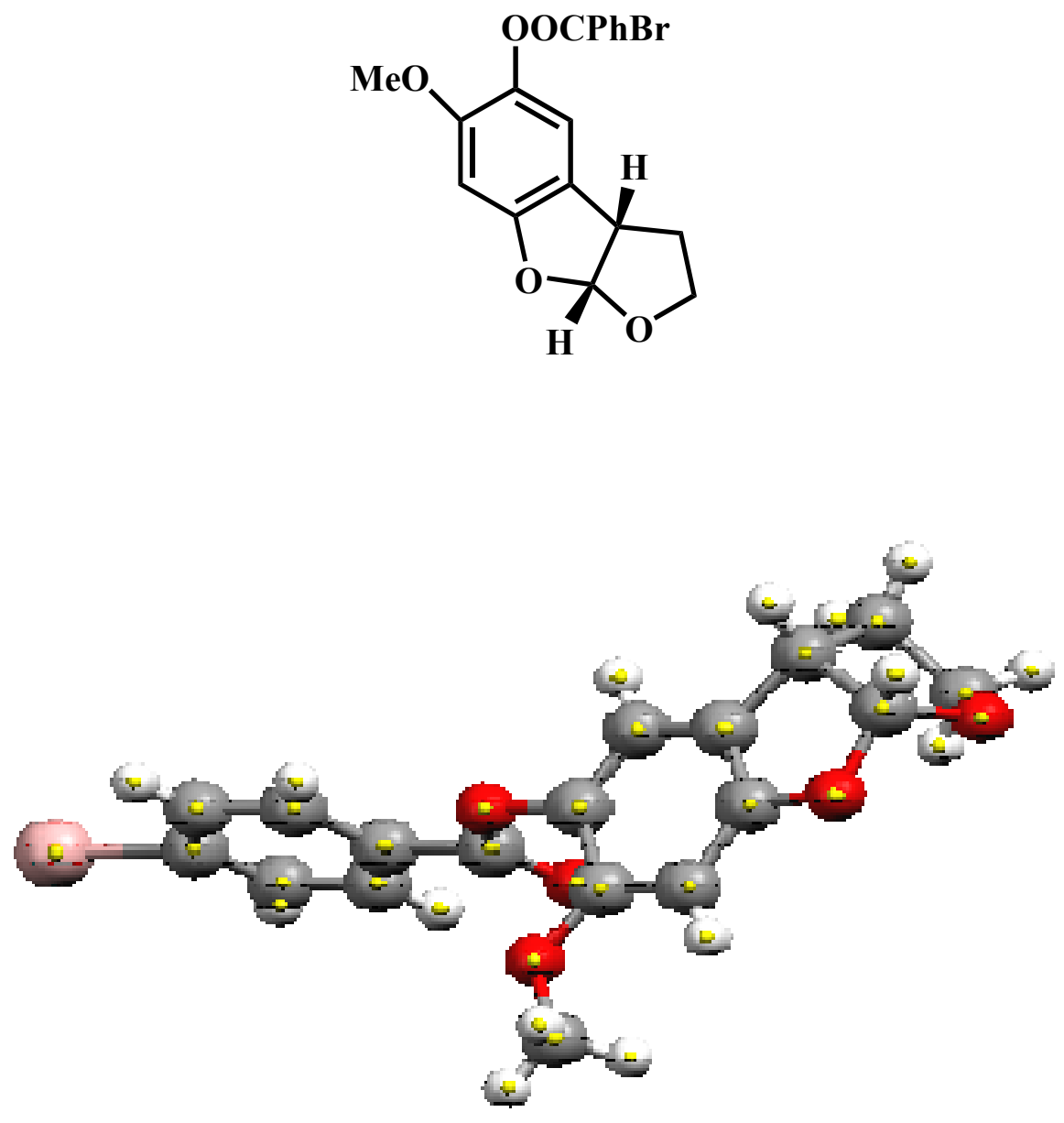
X-ray Structure of $\quad(+)-2,3,3 a R, 8 a S$-Tetrahydro-5-hydroxy-7-methoxy-[2,3-d]benzo[b]furan
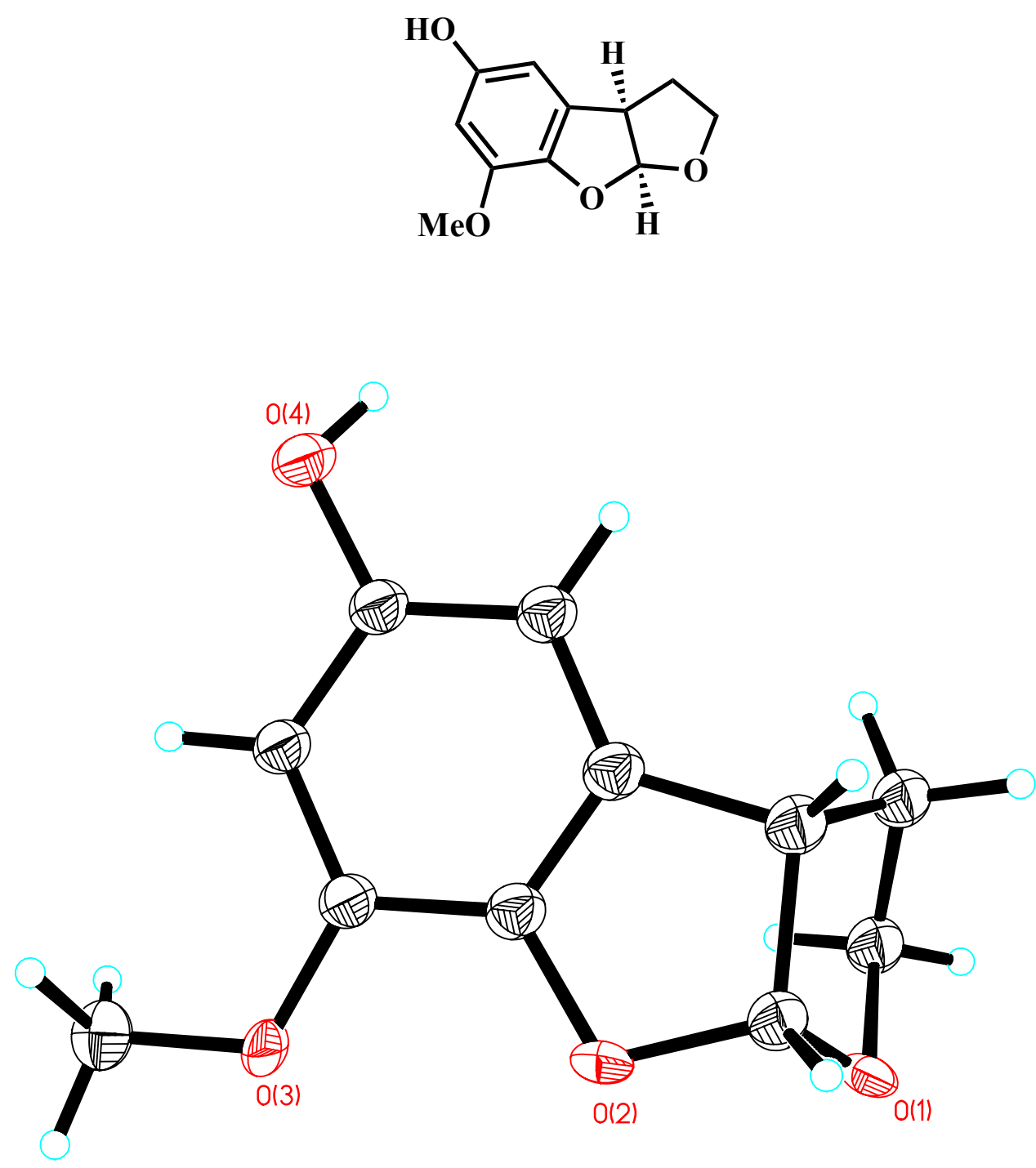
X-ray Structure of (+)-2,3,3aR,8aS-Tetrahydro-5-hydroxy-6-methoxy-7-isopropyl-[2,3-d]benzo $[b]$ furan
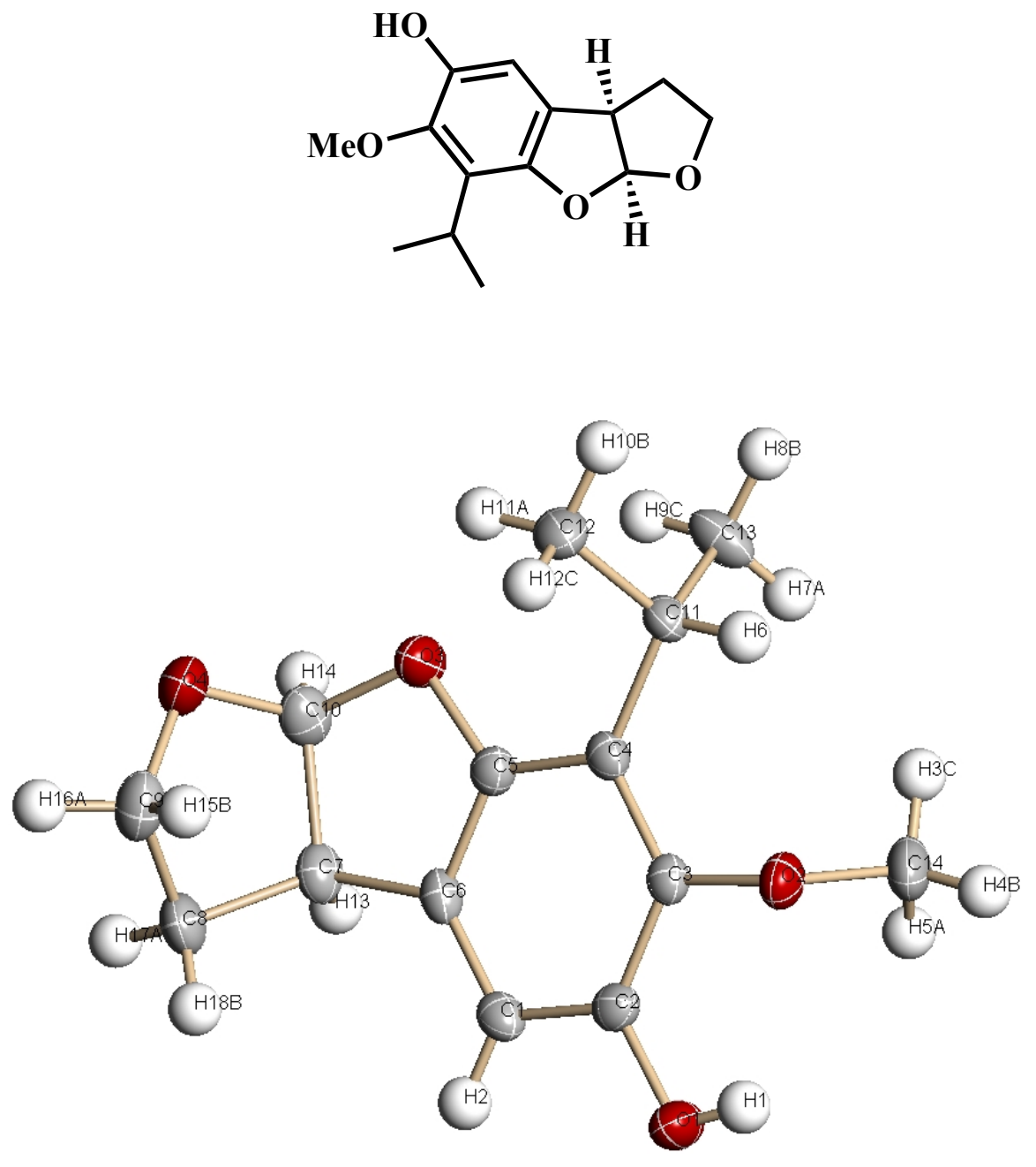
X-ray Structure of Compound 11:
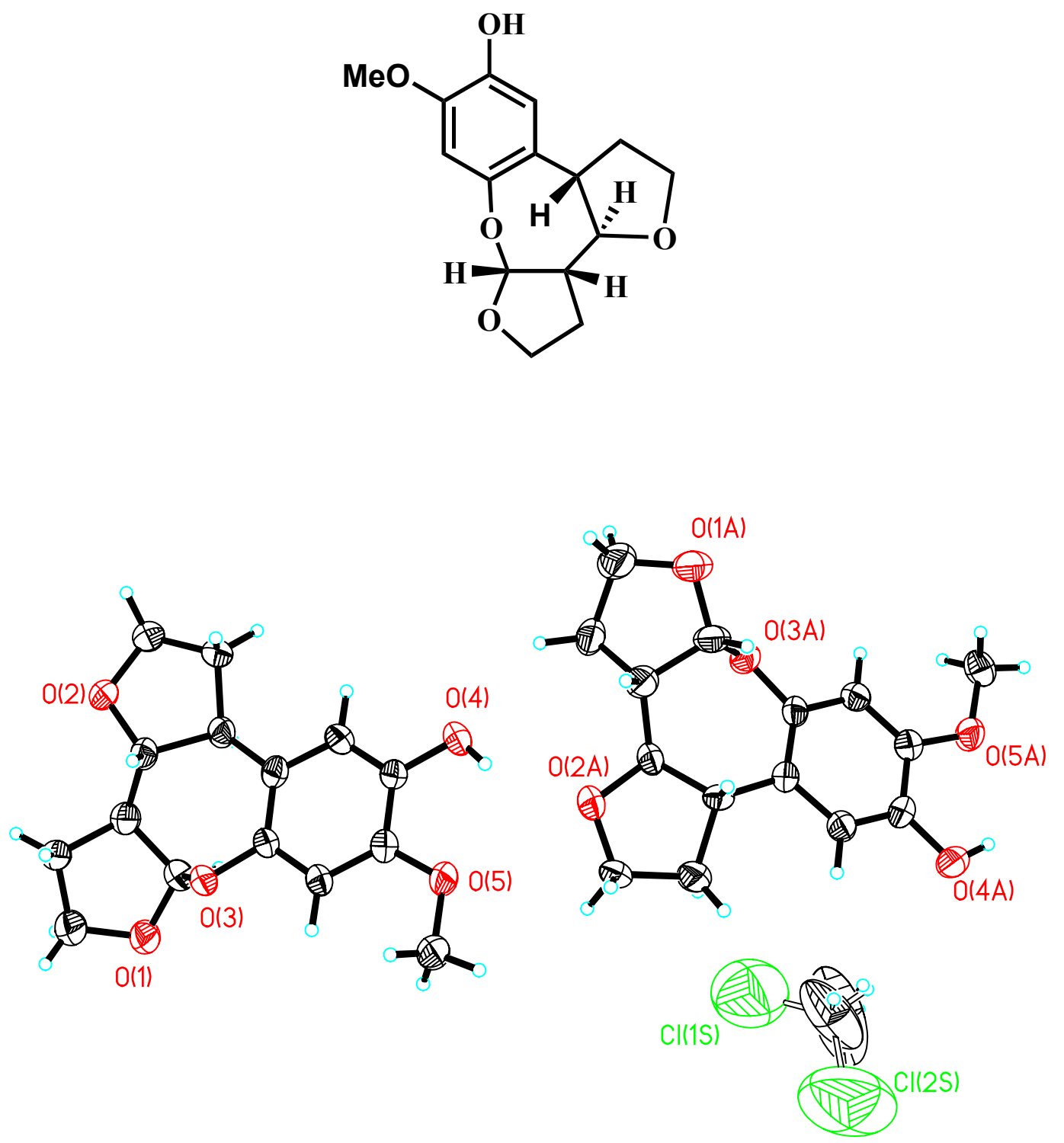